Данілова І. С., кандидат ветеринарних наук

Національний науковий центр «Інститут експериментальної і клінічної ветеринарної медицини»

\title{
ВПЛИВ ТЕРМІЧНОЇ ОБРОБКИ НА ВМІСТ НЕОРГАНІЧНИХ ЕЛЕМЕНТІВ У М'ЯСІ РАВЛИКІВ
}

\section{Рецензент - кандидат ветеринарних наук І. В. Коваленко}

Мета статmі. Дослідити вміст неорганічних елементів у вареному м'ясі харчових видів равликів Helix pomatia, Helix aspersa maxima ma Helix aspersa muller ma проаналізувати одержані результати.

Методика досліджень. Вміст неорганічних елементів визначали за допомогою рентгенофлуоресцентного аналізу на приладi «Спектроскан-МАКC - G» $Н B O$ «Спектрон». Для иього було сформовано 3 середні проби вареного м'яса равликів по 20,0 $\pm 0,5$ г кожного виду. М'ясо було термічно оброблене впродовж 90 хвилин, бо саме за такий час м'ясо вважається готовим до вживання.

Результати дослідження. Під впливом високої температури збільшилася кількість брому, цинку, стронцію, феруму і мангану та зменьшилася кількість купруму, кобальту, тоді як плюмбуму взагалі не виявлено порівняно із сирим м'ясом. Дані щьодо вмісту неорганічних елементів були оприлюднені в раніше опублікованій роботі.

Елементи наукової новизни. Вперше в Україні вивчено наявність $і$ кількість неорганічних елементів у вареному м'ясі равликів Helix pomatia, Helix aspersa maxima, Helix aspersa muller, які є харчовими видами і використовуються як делікатес.

Практична значущість. Поряд з амінокислотним та вітамінним складом нами вивчено питання складу неорганічних елементів у вареному м'ясі равликів. Одержані нові дані ввійдуть до методичних рекомендацій.

Ключові слова: неорганічні елементи, м'ясо, равлик, термічна обробка.

Данілова Ірина Сергіївна - кандидат ветеринарних наук, завідувач лабораторії з питань біобезпеки, управління якістю та метрології, Національний науковий центр «Інститут експериментальної і клінічної ветеринарної медицини», вул. Пушкінська, 83, м. Харків, 61023, e-mail: irrulik@meta.ua, ORCID ID: 0000-0003-1345-9622.

Постановка проблеми. Визначення вмісту елементів у м'ясі, кормах, мінеральних добавках, різних тканинах живого організму становить великий науковий і практичний інтерес. Виявлення закономірностей і характеру змін їх хімічного складу під впливом навколишнього середовища, термічної обробки тощо, встановлення показників якості i безпечності продукції вимагає додаткового вивчення $[1,3]$.

Неорганічні елементи є складовими компонентами ферментів та гормонів. Їх налічується понад 50 - це такі, як: бор (В), кобальт (Со), купрум $(\mathrm{Cu})$, молібден (Мo), цинк $(\mathrm{Zn})$, ванадій $(\mathrm{V})$, йод (I), бром (Br), манган $(\mathrm{Mn})$.

Усі елементи, що містяться в клітині живих організмів, входять до складу органічних і неорганічних сполук або перебувають у вигляді йонів. Вони відіграють велику роль у живленні клітин, їхньому рості, побудові тканин та органів, підтримують кислотно-лужну рівновагу, беруть участь в обміні речовин та енергії, у процесах подразнення та збудження клітини [10].

3 узагальнених даних та інтересу, який був ви- кликаний у науковців у галузі ветеринарної медицини та біології $\epsilon$ такий елемент, як плюмбум (свинець). Понад 4000 років людству відома його властивість накопичуватися і діяти, як кумулятивна отрута. Він $є$ основним забруднювачем навколишнього середовища [5]. За свинцевого токсикозу вражаються насамперед органи кровотворення (анемія), нервова система (енцефалопатія й нейропатія) і нирки (нефропатія). Найбільш сприйнятлива до свинцю гематопоетична система, також спостерігається пригнічення низки гемвмісних ферментів [3].

Патологічні зрушення за свинцевого токсикозу часто пояснюються взаємодією цього елемента 3 іншими металами, щонайперше, 3 кальцієм, магнієм і натрієм.

Ще одним високонебезпечним елементом I класу небезпеки поряд зі свинцем $є$ селен. Ступінь його токсичності залежить від характеру раціону, способу введення, виду тварин. У тварин та птиці спостерігається зниження маси тіла, затримка росту, зниження заплідненості яєць, порушення з боку нервової системи (паралічі), випадіння волосся, 


\section{ВЕТЕРИНАРНА МЕДИЦИНА}

сухість шкіри, враження копит [6] .

Однак високі дози кожного 3 вивчаємих нами неорганічних елементів можуть спричинити ознаки отруєння і викликати ефекти, які описані вище.

Аналіз останніх досліджень і публікацій, у яких започатковано розв'язання проблеми. Проаналізовано методичні вказівки, навчальні посібники, підручники, нормативно-правову базу документів стосовно даних досліджень. Після ретельного опрацювання джерел мережі Інтернет встановлено, що нами вперше не тільки в Україні було визначено вплив термічної обробки на наявність неорганічних елементів у м'ясі равликів Helix aspersa maxima, Helix aspersa muller, Helix pomatia [2, 4, 6, 7, 8, 9]. Ми порівнювали наші дані з даними, що одержали вчені Ferhat Çağıltay, Nuray Erkan, Deniz Tosun, Arif Selçuk. (Стамбул, Турція). Турецькі вчені вивчали мінеральний склад м'яса равликів лише за 6 елементами, тоді як нами вивчено наявність 12 елементів. Наші дані збігаються 3 даними колег лише по 3 елементам: феруму, мангану та кальцію [11].

Метою нашої роботи було дослідити вміст неорганічних елементів у вареному м'ясі харчових видів равликів $H$. pomatia, $H$. aspersa maxima та $H$. aspersa muller та провести аналіз одержаних результатів.

Завдання - у вареному м'ясі равликів трьох видів визначити вміст неорганічних елементів.

Матеріал та методи досліджень. Дослідження проводилися у лабораторії токсикологічного моніторингу Національного наукового центру «Інститут експериментальної і клінічної ветеринарної медицини» 3 використанням рентгенофлуоресцентного методу у трьох повтореннях. Для цього було сформовано 3 середніх проби вареного м'яса равликів по 20,0 $\pm 0,5$ г кожного виду. М'ясо термічно оброблялося впродовж 90 хвилин, бо саме за такий час м'ясо вважається готовим до вживання. Равликів виду Helix pomatia (виноградний равлик) збирали самостійно у сиру погоду, особливо після дощу, а іноді вранці, Helix aspersa maxima та Helix aspersa muller були отримані з фермерського господарства «РАВЛИК 2016» (Україна). Середню пробу м'яса равликів було сформовано самостійно безпосередньо перед дослідженнями.

Вміст неорганічних елементів визначали за допомогою рентгенофлуоресцентного аналізу, згідно 3 методичними рекомендаціями (О.О. Малинін та ін.) [4]. Метод рентгенофлуоресцентного аналізу грунтується на використанні рентгенівської флуо- ресценції елементів 3 подальшим аналізом спектрів на приладі «Спектроскан-МАКС - G» НBO «Спектрон». Основні параметри приладу за вимірювання спектральних показників: перше відображення - від 950 мА до 3150 мА, друге відображення - від 315 мА до 1575 мА. Величина кроку приладу і час експозиції дорівнювали 4 [6].

За опромінення зразка рентгенівськими променями біологічний об'єкт, який заздалегідь підданий сухій мінералізації, починає випромінювати (флуоресціювати) в рентгенівському діапазоні. Спектр цієї вторинної флуоресценції адекватно відображає елементний склад аналізованого зразка.

Суміш елементів підбирали з таким розрахунком, щоби спектр внесених елементів не накладався один на одного. Специфічні показники довжини хвилі флуоресценції перевіряли за каталогом спектрів, а для визначення маси елементів ураховували кількість імпульсів флуоресценції, характерних для кожного 3 елементів. Результати були оброблені статистично.

Результати досліджень. Нами було визначено вміст 12 неорганічних елементів у вареному м'ясі равликів кожного виду, взятих для досліджень. Результати наведені в таблицях 1, 2 та 3.

Унаслідок проведених нами досліджень щодо вмісту неорганічних елементів у вареному м'ясі равликів, які наведені в таблицях 1, 2 та 3 встановлено, що найбільше воно збагачено кальцієм і ста-

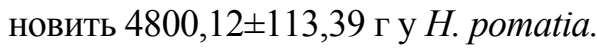

Також м'ясо усіх трьох видів равликів збагачене такими елементами, як манган, цинк, ферум та стронцій. Велика кількість елементу стронцію $54,52 \pm 2,31$ г у виноградного равлика пояснюється ймовірністю забрудненого грунту, у якому він постійно мешкав. Тоді як два інших види равликів вирощувалися и утримувалися штучно в умовах ферми.

У нашій попередній опублікованій роботі вже були надані результати щодо вмісту неорганічних елементів у сирому м'ясі равликів i, порівнюючи ці дані, можна зробити висновок, що за впливу термічної обробки у м'ясі равликів $H$. pomatia та $H$. aspersa muller плюмбуму не було виявлено, тоді як H. aspersa maxima плюмбум відсутній, як у сирому, так і у вареному м'ясі.

Отже, у вареному м'ясі усіх трьох видів равликів, які нами вивчалися, кумулятивного металу плюмбуму не виявлено. 
ВЕТЕРИНАРНА МЕДИЦИНА

\section{1. Вміст неорганічних елементів у вареному м'ясі равликів Н. ротаtia}

\begin{tabular}{|c|c|c|c|c|}
\hline \multirow{2}{*}{$\begin{array}{l}\text { Проба } \\
\text { Елемент, } \\
\text { мГ/кг }\end{array}$} & \multicolumn{3}{|c|}{ Проба 1 H. pomatia } & \multirow{2}{*}{$\mathrm{M} \pm \mathrm{m}$} \\
\hline & Повторність 1 & Повторність 2 & Повторність 3 & \\
\hline Стронцій & 58,66 & 54,22 & 50,67 & $54,52 \pm 2,31$ \\
\hline Бром & 1,82 & 2,50 & 3,73 & $2,68 \pm 0,56$ \\
\hline Селен & 0,09 & 0,12 & 0,10 & $0,10 \pm 0,01$ \\
\hline Плюмбум & Не виявлено & Не виявлено & Не виявлено & - \\
\hline Цинк & 56,04 & 53,90 & 55,67 & $55,20 \pm 0,66$ \\
\hline Купрум & 1,92 & 1,84 & 1,62 & $1,79 \pm 0,09$ \\
\hline Нікель & 0,23 & 0,20 & 0,28 & $0,24 \pm 0,02$ \\
\hline Кобальт & 0,027 & 0,034 & 0,030 & $0,030 \pm 0,01$ \\
\hline Ферум & 42,84 & 40,50 & 38,48 & $40,61 \pm 1,26$ \\
\hline Манган & 25,12 & 24,30 & 25,17 & $24,86 \pm 0,28$ \\
\hline Хром & 0,19 & 0,19 & 0,15 & $0,18 \pm 0,01$ \\
\hline Кальцій & 4755,00 & 5015,15 & 4630,21 & $4800,12 \pm 113,39$ \\
\hline
\end{tabular}

Джерело: власні дослідження.

2. Вміст неорганічних елементів у вареному м'ясі равликів Н. аspersa тахіма

\begin{tabular}{|c|c|c|c|c|}
\hline \multirow{2}{*}{$\begin{array}{l}\text { Проба } \\
\text { Елемент, } \\
\text { мг/кг }\end{array}$} & \multicolumn{3}{|c|}{ Проба 1 H. aspersa maxima } & \multirow{2}{*}{$\mathrm{M} \pm \mathrm{m}$} \\
\hline & Повторність 1 & Повторність 2 & Повторність 3 & \\
\hline Стронцій & 35,56 & 34,98 & 34,66 & $35,07 \pm 0,26$ \\
\hline Бром & 2,46 & 2,52 & 2,77 & $2,58 \pm 0,09$ \\
\hline Селен & 0,11 & 0,10 & 0,12 & $0,11 \pm 0,01$ \\
\hline Плюмбум & Не виявлено & Не виявлено & Не виявлено & - \\
\hline Цинк & 42,74 & 42,37 & 42,83 & $42,65 \pm 0,14$ \\
\hline Купрум & 1,28 & 1,32 & 1,28 & $1,29 \pm 0,01$ \\
\hline Нікель & 0,29 & 0,27 & 0,30 & $0,29 \pm 0,01$ \\
\hline Кобальт & 0,033 & 0,029 & 0,037 & $0,031 \pm 0,01$ \\
\hline Ферум & 30,83 & 31,08 & 29,96 & $30,62 \pm 0,34$ \\
\hline Манган & 77,41 & 76,63 & 78,41 & $77,48 \pm 0,52$ \\
\hline Хром & 0,23 & 0,22 & 0,24 & $0,23 \pm 0,01$ \\
\hline Кальцій & 3280,62 & 3302,01 & 3285,62 & $3289,42 \pm 6,46$ \\
\hline
\end{tabular}

Джерело: власні дослідження.

Необхідно зазначити, що у вареному м'ясі равликів міститься 11 неорганічних елементів: стронцій, бром, селен, цинк, купрум, нікель, кобальт, ферум, манган, хром та кальцій і його можна використовувати, як джерело, збагачене такими елементами.

Ми порівнювали наші дані, 3 даними, що одержали вчені Ferhat Çağıltay, Nuray Erkan, Deniz Tosun, Arif Selçuk. Ці вчені вивчали мінеральний склад м'яса равликів лише за 6 елементами, тоді як нами вивчено наявність 12 елементів. Наші дані збігаються 3 даними колег лише по 3 елементам: феруму, мангану та кальцію. 
ВЕТЕРИНАРНА МЕДИЦИНА

3. Вміст неорганічних елементів у вареному м'ясі равликів Н. aspersa muller

\begin{tabular}{|c|c|c|c|c|}
\hline \multirow{2}{*}{$\begin{array}{l}\text { Проба } \\
\text { Елемент, } \\
\text { мг/кг }\end{array}$} & \multicolumn{3}{|c|}{ Проба 1 H. aspersa muller } & \multirow{2}{*}{ М $\pm \mathrm{m}$} \\
\cline { 1 - 4 } Стронцій & Повторність 1 & Повторність 2 & Повторність 3 & \\
\hline Бром & 36,12 & 35,91 & 35,73 & $35,92 \pm 0,11$ \\
\hline Селен & 2,01 & 2,19 & 2,09 & $2,10 \pm 0,05$ \\
\hline Плюмбум & 0,12 & 0,12 & 0,10 & $0,11 \pm 0,01$ \\
\hline Цинк & Не виявлено & Не виявлено & Не виявлено & - \\
\hline Купрум & 42,21 & 42,28 & 44,92 & $43,14 \pm 0,89$ \\
\hline Нікель & 2,06 & 2,63 & 1,77 & $2,15 \pm 0,25$ \\
\hline Кобальт & 0,39 & 0,44 & 0,37 & $0,40 \pm 0,02$ \\
\hline Ферум & 0,044 & 0,043 & 0,044 & $0,04 \pm 0,01$ \\
\hline Манган & 35,65 & 34,84 & 36,24 & $35,58 \pm 0,41$ \\
\hline Хром & 52,03 & 52,78 & 53,44 & $52,75 \pm 0,41$ \\
\hline Кальцій & 0,64 & 0,60 & 0,67 & $0,64 \pm 0,02$ \\
\hline
\end{tabular}

Джерело: власні дослідження.

У м'ясі равликів, які досліджувалися нами, показники наявності феруму та кальцію перевищують у 4-6 разів, тоді як мангану менше у 2,3 рази, ніж такі дані, одержані колегами зі Стамбулу. Це можна пояснити тим, що равлики $H$. aspersa maxima та H. aspersa muller вирощувалися у штучних умовах і отримували збалансований раціон, а вчені Ferhat Çağıltay, Nuray Erkan, Deniz Tosun, Arif Selçuk досліджували равликів, яких відбирали вздовж узбережжя Анатолії (Стамбул) [11].

Висновки. Вперше в Україні було вивчено вплив термічної обробки на кількість неорганічних елементів у м'ясі равликів $H$. pomatia, $H$. aspersa maxima, $H$. aspersa muller, які є харчовими

видами і використовуються як делікатес. М'ясо равликів є джерелом 11 неорганічних елементів: стронцію, брому, селену, цинку, купруму, нікелю, кобальту, феруму, мангану, хрому та кальцію. Під впливом високої температури збільшилася кількість брому, цинку, стронцію, феруму і мангану та зменьшилася кількість купруму, кобальту, тоді як плюмбуму взагалі не було виявлено порівняно із сирим м'ясом.

У перспективі необхідно з'ясувати вміст неорганічних елементів у м'ясі равликів $H$. pomatia, $H$. aspersa maxima, $H$. aspersa muller після його термічної обробки за різного часу варіння та зробити порівняльний аналіз.

\section{БІБЛІОГРАФІЯ}

1. Данілова I. C. Уміст неорганічних елементів у м'ясі равликів / І. С. Данілова. Науковий вісник Львівського національного університету ветеринарної медицини та біотехнологій імені С. 3. Гжицького. Серія : Ветеринарні науки. 2018. № 83, т. 20. С. 189-193.

2. Ершов Ю. А. Общая химия. Биофизическая химия. Химия биогенных элементов: монография. Москва : Высшая школа, 2003. $560 \mathrm{c}$.

3. Експрес-довідник з ветеринарно-санітарної експертизи у запитаннях та відповідях / Труш А. М. та ін. Харків : 2009. 248 с.

4. Малинін О.О. Визначення неорганічних

елементів у біологічних субстратах методом рентгенофлуоресцентного аналізу: метод. вказівки. Київ : затв. ДКВМ України 23-24.12.2009 р., протокол № $1.30 \mathrm{c}$.

5. Маньковський А. Я., Антонюк Т. А. Технологія продуктів забою тварин : Київ : Агроосвіта, 2014. $336 \mathrm{c}$.

6. Кучан О.Т., Оробченко О. Л., Кочергін Ю. А. Токсико-біохімічна характеристика неорганічних елементів та застосування рентгенофлуоресцентного аналізу у ветеринарній медицині: монографія. Харків : Планета-прінт, 2014. $300 \mathrm{c}$.

7. Обов'язковий мінімальний перелік дослі- 


\section{ВЕТЕРИНАРНА МЕДИЦИНА}

джень сировини, продукції тваринного та рослинного походження, комбікормової сировини, комбікормів, вітамінних препаратів та ін., які слід проводити в державних лабораторіях ветмедицини і за результатами яких видається свідоцтво (Ф-2): затв. наказом Держ. департамента ветмедицини Мін-ва аграрної політики України від 28 квіт. 2004 р., № 549/9148.

8. Санитарно-гигиенические методы исследования пищевых продуктов и воды / Яцула Г. С. и др. Київ : Здоровье, 1991. 288 с.

9. Babalola O. O. and Akinsoyinu A. O. Proximate Composition and Mineral Profile of Snail Meat from Different Breeds of Land Snail in Nige-

\section{REFERENCES}

1. Danilova, I. S. (2018). Umist neorhanichnykh elementiv $u$ myasi ravlykiv [The content of inorganic elements in the meat of snails]. Naukovyy visnyk Lvivskoho natsionalnoho universytetu veterynarnoyi medytsyny ta biotekhnolohiy imeni S. Z. Gzhytskoho. Seriya: Veterynarni nauky, 83, pp.189193 [In Ukrainian].

2. Yershov, Yu. A. (2003). Obshchaya khimiya. Biofizicheskaya khimiya. Khimiya biogennykh elementov: monohrafiia. [General chemistry. Biophysical chemistry. Chemistry of biogenic elements: monograph]. Moskva: Vysshaya shkola [In Russian].

3. Trush, A. M., Yatsenko, I. V., \& Dehtyarov, M. O. (2009). Ekspres-dovidnyk $z$ veterynarnosanitarnoyi ekspertyzy u zapytannyakh ta vidpovidyakh: monohrafiia [Express-reference book on veterinary and sanitary examination in questions and answers: monograph]. Kharkiv [In Ukrainian].

4. Malynin, O. O. Vyznachennya neorhanichnykh elementiv u biolohichnykh substratakh metodom renthenofluorestsentnoho analizu: metod. vkazivky [Determination of inorganic elements in biological substrates by X-ray fluorescence analysis: method. instructions]. Kyiv: zatv. DKVM Ukrayiny 23-24.12.2009., protokol № 1 . [In Ukrainian].

5. Mankovskyy, A. Ya. \& Antonyuk, T. A. (2014). Tekhnolohiya produktiv zaboyu tvaryn: pidruchnyk [Technology products slaughter tvarin: monograph]. Kyiv: Ahroosvita [In Ukrainian].

6. Kutsan, O. T., Orobchenko, O. L. \& Kocherhin, Yu. A. (2014). Toksyko-biokhimichna kharakterystyka neorhanichnykh elementiv ta zastosuvannya renthenofluorestsentnoho analizu $u$ veterynarniy medytsyni: monohrafiia [Toxic-biochemical characteristic of inorganic elements and application of X-ray fluorescence analysis in veterinary ria. Pakistan Journal of Nutrition. 2009. Vol. 8. P.1842-1844.

10. Felix Narku Engmann, Newlove Akowuah Afoakwah, Patricia Owusu Darko, Wilfred Sefah. Proximate and Mineral Composition of Snail (Achatina achatina) Meat; Any Nutritional Justification for Acclaimed Health Benefits? J. Basic. Appl. Sci. Res. 2013. Vol. 3 (4). P. 8-15.

11. Ferhat Çă̆lltay, Nuray Erkan, Deniz Tosun, Arif Selçuk. Amino acid, fatty acid, vitamin and mineral contents of the edible garden snail (helix aspersa). Journal of Fisheries Sciences. 2011. Vol. 5 (4). P. 354-363.

medicine: monograph]. Kharkiv : Planeta-print [In Ukrainian].

7. Obovyazkovyy minimalnyy perelik doslidzhen syrovyny, produktsiyi tvarynnoho ta roslynnoho pokhodzhennya, kombikormovoyi syrovyny, kombikormiv, vitaminnykh preparativ ta in., yaki slid provodyty $v$ derzhavnykh laboratoriyakh vetmedytsyny $i$ za rezultatamy yakykh vydayetsya svidotstvo (F-2): zatv. nakazom Derzhavnym departamentom vetmedytsyny Minahropolityky Ukrainy vid $28 \mathrm{kvit}$. 2004 r. \# 549/9148 [Mandatory minimum list of researches of raw materials, products of animal and vegetable origin, feed materials, mixed fodders, vitamin preparations, etc. to be carried out in state veterinary laboratories and on the basis of which a certificate (F-2) is issued]. (2004) [In Ukrainian].

8. Yatsula, G. S., Slobodkin, V. I. \& Bereza, V. Ya. (1991). Sanitarno-gigiyenicheskiye metody issledovaniya pishchevykh produktov $i$ vody: monohrafiia [Sanitary and hygienic methods for the study of food and water: monograph]. Kyiv: Zdorov'ya [In Ukrainian].

9. Babalola, O. and Akinsoyinu, A. (2009). Proximate Composition and Mineral Profile of Snail Meat from Different Breeds of Land Snail in Nigeria. Pakistan: Journal of Nutrition. Retrieved from: https://scialert.net/fulltextmobile/?doi =pjn.2009.18 42.1844 [In Pakistan].

10. Engmann, F., Afoakwah, N., Darko, P., and Sefah, W. (2013). Proximate and Mineral Composition of Snail (Achatina achatina) Meat; Any Nutritional Justification for Acclaimed Health Benefits?. England: J. Basic. Appl. Sci. Res. Retrieved from:http:/www.pdfs.semanticscholar.org/fe8d/8f2 a55cdd6e82be1391e3f34ddc10ffdba49.pdf [In English].

11. Ferhat, Çağıltay, Nuray, Erkan, Deniz, Tosun, Arif, Selçuk (2011). Amino acid, fatty acid, 


\section{ВЕТЕРИНАРНА МЕДИЦИНА}

vitamin and mineral contents of the edible garden snail (helix aspersa). Turkish: Journal of Fisheries Sciences. Retrieved from: https://www.researchgate.
net/publication/268376942_Amino_acid_fatty_acid _vitamin_and_mineral_contents_of_the_edible_gar den_snail_Helix_aspersa [In Turkish].

Данилова И. С. Влияние термической обработки на содержание неорганических элементов в мясе улиток

Цель статьи - исследовать содержимое неорганических элементов в вареном мясе пищевых видов улиток Helix pomatia, Helix aspersa maxima и Helix aspersa muller и проанализировать полученные результатьл.

Методика исследований. Содержание неорганических элементов определяли с помощью рентгенофлуоресцентного анализа на приборе «Спектроскан-МАКС - G» НПО «Спектрон». Для этого было сформировано 3 средних пробы вареного мяса улиток по 20,0 \pm 0,5 г каждого вида. Мясо было подвергнуто термической обработке в течение 90 минут, потому что именно за такое время мясо считается готовым к употреблению.

Результаты исследований. Под воздействием высокой температурь увеличилось количество брома, цинка, стронция, железа, марганцуа и уменьшилась количество меди и кобальта, а свинца вообще не обнаружено по сравнению с сырым мясом. Данные по содержанию неорганических элементов были опубликованы в нашей предылущей работе.

Элементы научной новизны. Нами впервые не только в Украине было выявлено наличие и измеряно количество неорганических элементов в вареном мясе улиток Helix pomatia, Helix aspersa maxima, Helix aspersa muller, которые являются пищевыми видами и используются как деликатес.

Практическая значимость. Наряду с аминокислотным и витаминным составами нами изучен вопрос состава неорганических элементов в вареном мясе улиток. Полученные новые данные войдут в методические рекомендации.

Ключевые слова: неорганические элементы, мясо, улитка, термическая обработка.

Данилова Ирина Сергеевна - кандидат ветеринарных наук, заведующая лабораторией по вопросам биобезопасности, управления качеством и метрологии, Национальный научный центр «Институт экспериментальной и клинической ветеринарной медицины», ул. Пушкинская, 83, г. Харьков, 61023, e-mail: irrulik@meta.ua, ORCID ID: 0000-0003-1345-9622.

\section{Danilova I. S. The influence of thermal processing on the content of inorganic elements in snail meat}

The purpose of the article was to investigate the content of inorganic elements in cooked meat of food species Helix pomatia, Helix aspersa maxima and Helix aspersa muller snails and to analyze the obtained results.

Methods of the research. The content of inorganic elements was determined using X-ray fluorescence analysis in three replicates on the Spectroscan-MAX-G device of the Spectron RPA. The first reflection was the main parameter of the instrument for measuring spectral indicators. The value of the device step and the exposure time was 4. For this, 3 medium samples of boiled snail meat $20.0 \pm 0.5 \mathrm{~g}$ of each species were taken. The meat was subjected to heat treatment for 90 minutes, because during this time the meat is considered to be ready for consumption.

The research results. For the first time, not only in Ukraine, but also in the world, the influence of heat treatment on the amount of inorganic elements in the meat of Helix pomatia, Helix aspersa maxima, Helix aspersa muller, which are edible species and used as a delicacy, was studied. Snail meat is a source of 11 inorganic elements: strontium, bromine, selenium, zinc, cuprum, nickel, cobalt, ferrum, manganese, chromium, and calcium. Under the influence of high temperature, the amount of bromine, zinc, strontium, ferrum and manganese increased, and the amount of cuprum, cobalt decreased, while plumbum was not detected at all as compared with raw meat.

Elements of scientific novelty. For the first time not only in Ukraine, but also in the world, we have studied the presence and number of inorganic elements in boiled meat of snails Helix pomatia, Helix aspersa maxima, Helix aspersa muller, which are food types and are used as a delicacy.

Practical significance. Along with amino acid and vitamin compositions, we studied the question of inorganic elements' composition in boiled snail meat. The obtained new data will be included in the

№ 1 • 2019 • ВІСНИК Полтавської державної аграрної академії 
methodical recommendations.

Key words: inorganic elements, meat, snail, thermal treatment.

Danilova Iryna Serhiivna - Candidate $(\mathrm{PhD})$ of Veterinary Sciences, Head of the Laboratory for Biosafety, Quality Management and Metrology of the National Scientific Center the "Institute of Experimental and Clinical Veterinary Medicine", 83, Pushkinska str., Kharkiv, 61023, e-mail: irrulik@meta.ua, ORCID ID: 0000-0003-1345-9622.

\section{Стаття надійшла до редакції 14.02.2019 р.}

Бібліографічний опис для цитування :

Данілова I. С. Вплив термічної обробки на вміст неорганічних елементів у м'ясі равликів. Вісник ПДАА. 2019. № 1. С. 200-206.

DOI 10.31210/visnyk2019.01.23

(с) Данілова Ірина Сергіївна, 2019 